\title{
Pengaruh demonstrasi penggunaan buku pop up sebagai media pembelajaran terhadap motivasi dan penguasaan konsep siswa pada materi sistem endokrin (The effect of using the pop up book demonstration as learning media on students motivation and concept mastery in endocrine system materials)
}

\author{
Nada Nurhanifah, Yanti Hamdiyati*, Yayan Sanjaya \\ Departemen Pendidikan Biologi FPMIPA Universitas Pendidikan Indonesia, Jl. Dr. Setiabudhi No.229 Bandung \\ *Corresponding author: yhamdiyati@upi.edu
}

Received: 24 July 2020 - Accepted: 2 September 2020 - Published: 30 September 2020

\begin{abstract}
This research was conducted to determine the increase in students' mastery of the endocrine system material and learning motivation after using learning media in the form of pop up books by demonstration methode because this learning is carried out in the midst of a pandemic that requires students to learn from home. The method that used in this research was experimental research using quasi-experimental research involving two classes, each consisting of 36 students of class XI Science. Determination of the sample was done by using purposive sampling technique. The instrument in this study consisted of tests containing a matter of mastery of the concept of multiple choice forms, and nontest namely the ARCS learning motivation questionnaire and student response questionnaire. Analysis of research results using statistical tests with the help of SPSS to see differences in the results of the initial test and final test, and $\mathrm{N}$-gain to see an increase in mastery of concepts. The results showed that the initial and final test scores had significant differences $(\alpha=0.05)$. Reinforcement of concepts in the experimental class increases with the high category $(<\mathrm{g}>=0.806)$, while the control class increases in the moderate category $(<\mathrm{g}>=0.656)$. ARCS (Attention, Relevance, Confidence, Satisfaction) are in the high category. Meanwhile, questionnaire analysis showed higher student responses to learning.
\end{abstract}

Keywords learning media, pop up books, mastery of concepts, learning motivation, endocrine system

\begin{abstract}
ABSTRAK Penelitian ini dilakukan untuk mengetahui peningkatan penguasaan konsep siswa dalam materi sistem endokrin dan motivasi belajar setelah menggunakan media pembelajaran berupa buku pop up yang dilakukan dengan demonstrasi karena pembelajaran ini dilakukan di tengah pandemi yang mengharuskan siswa belajar dari rumah. Metode penelitian yang digunakan adalah penelitian eksperimen dengan menggunakan quasi experiment yang melibatkan dua kelas penelitian yang masing-masing terdiri dari 36 siswa SMA kelas XI IPA. Penentuan sampel dilakukan dengan menggunakan tekni purposive sampling. Instrumen dalam penelitian ini terdiri dari tes berupa soal penguasaan konsep bentuk pilihan ganda, dan nontes yaitu angket motivasi belajar ARCS serta angket respon siswa. Analisis hasil penelitian menggunakan uji statistika dengan bantuan SPSS untuk melihat perbedaan hasil tes awal dan tes akhir, serta $\mathrm{N}$-gain untuk melihat peningkatan penguasaan konsep. Hasil penelitian menunjukkan nilai tes awal dan tes akhir memiliki perbedaan yang signifikan $(\alpha=0,05)$. Penguasaan konsep dalam kelas eksperimen mengalami peningkatan dengan kategori tinggi $(<\mathrm{g}>=0,806)$, sedangkan kelas kontrol mengalami peningkatan dalam kategori sedang $(<\mathrm{g}>=0,656)$. Adapun motivasi belajar pada keempat komponen ARCS (Attention, Relevance, Confidence, Satisfaction) berada dalam kategori tinggi. Sedangkan, analisis angket menunjukkan bahwa respon siswa adalah tinggi terhadap pembelajaran.
\end{abstract}

Kata kunci media pembelajaran, buku pop up, penguasaan konsep, motivasi belajar, sistem endokrin

\section{PENDAHULUAN}

Media pembelajaran dibutuhkan sebagai perantara dalam penyampaian materi dalam proses pembelajaran untuk meminimalkan kegagalan dalam penyampaian materi saat berlangsung sehingga proses pembelajaran lebih bermakna (Anggraini et al., 2019). Hal ini sesuai dengan pendapat Arsyad (2009) bahwa media pembelajaran dapat memperjelas penyajian informasi sehingga dapat memfasilitasi proses pembelajaran. Karena itulah, media pembelajaran menjadi salah satu faktor penting dalam pencapaian kompetensi siswa.

Djamarah et al. (2010) berpendapat bahwa kata media berasal dari bahasa Latin dan merupakan bentuk jamak dari kata medium, yang secara harfiah berarti perantara atau pengantar. Menurut Anwariningsih dan Ernawati (2013), media pembelajaran adalah segala sesuatu yang dapat dipergunakan untuk merangsang pikiran, perasaan, perhatian dan kemampuan atau keterampilan siswa sehingga dapat mendorong terjadinya proses belajar.

Ada banyak jenis media yang biasanya digunakan dalam proses pembelajaran, diantaranya adalah media tiga dimensi seperti buku pop up. Istilah pop up berasal dari kata bahasa inggris yang artinya muncul keluar. Pop up menurut Okamura \& Igarashi (2011) adalah selembar kertas yang dilipat dan struktur tiga dimensi akan muncul ketika dibuka. Buku pop up adalah buku berbentuk yang memiliki bagian bergerak dan memberikan visualisasi yang 
menarik ketika halaman dibuka. Menurut Khotimah (dalam Sari, 2017), visualisasi unik dari buku pop up dalam pemaparan materi untuk merangsang peserta didik untuk belajar, mengembangkan kapasitas, dan memfasilitasi peserta didik untuk mengingat materi dalam buku tersebut.

Menurut Wahyuningsih et al. (2015), peran media pembelajaran dalam proses pembelajaran dapat meningkatkan motivasi siswa dalam belajar. Motivasi belajar siswa dalam pendidikan adalah hal yang penting. Tanpa motivasi belajar hal-hal yang terjadi menjadi tidak mungkin. Dalam dunia pendidikan, peran motivasi mampu mengefektifkan pembelajaran. Adapun dalam penelitian ini untuk mengukur tingkat motivasi belajar siswa, peneliti mengadaptasi dari model ARCS. Model ARCS dikembangkan oleh Keller (2000) berdasarkan pada perpanduan konsep-konsep dan karakteristik-karakteristik motivasi, sehingga diperoleh empat kategori yaitu attention $(A)$, relevance $(\mathrm{R})$, confidence $(\mathrm{C})$, dan satisfaction $(\mathrm{S})$.

Berdasarkan uraian permasalahan di atas, penulis tertarik untuk mencari tahu pengaruh buku pop up sebagai media pembelajaran terhadap penguasaan konsep dan motivasi siswa pada materi sistem endokrin dengan cara demonstrasi media, karena penelitian ini dilaksanakan di tengah pandemi sehingga mengharuskan siswa belajar dari rumah. Sehingga media buku pop up dipaparkan melalui demonstrasi secara daring.

Materi yang digunakan dalam penelitian ini adalah materi sistem endokrin yang dipelajari pada semester genap di kelas XI SMA. Materi sistem endokrin mengacu pada KI dan KD sesuai dengan kurikulum 2013 revisi 2017.

\section{METODE}

Metode penelitian yang digunakan adalah penelitian eksperimen dengan menggunakan quasi experiment. Desain penelitian yang digunakan adalah non-equivalent control group.

Populasi penelitian ini yaitu penguasaan konsep dan motivasi siswa SMA kelas XI. Sampel yang digunakan dalam penelitian ini adalah sebanyak dua kelas yang akan mewakili seluruh kelas XI IPA yang diambil menggunakan teknik random sampling.

Data diperoleh dengan menggunakan instrumen soal pilihan ganda, angket motivasi belajar, dan angket respon siswa terhadap pembelajaran. Soal pilihan ganda pada tes awal dan tes akhir digunakan untuk mengetahui penguasaan konsep siswa sebelum dan sesudah proses pembelajaran. Adapun instrumen angket yang digunakan dalam penelitian ini diadaptasi dari model Attention, Relevance, Confidence, Satisfaction (ARCS) yang dikembangkan oleh John Keller (2000), komponen tersebut dimodifikasi oleh peneliti untuk megetahui tingkat motivasi belajar yang dimiliki siswa. Sementara itu, instrumen angket respon siswa digunakan untuk mendukung keakuratan data yang diperoleh dari proses pembelajaran yang telah dilaksanakan. Pembelajaran dilaksanakan melalui Cisco Webex sedangkan data penelitian dijaring menggunakan aplikasi Quizizz dan Google Form, hal tersebut dikarenakan penelitian ini dilakukan secara daring. Hasil dari penelitian ini diolah menggunakan program SPSS 16 (Uji Shapiro-Wilk, Levene's Test, dan Uji Mann-Whitney) dan Microsoft Excel 2010.

\section{HASIL DAN PEMBAHASAN}

\section{Penguasaan konsep siswa sebelum dan setelah pembelajaran menggunakan media pop up}

Penggunaan media buku pop up yang didemonstrasikan dalam proses pembelajaran menunjukkan hasil rata-rata tes awal dan tes akhir dengan kategori yang sama yaitu sangat tinggi. Meski begitu ratarata hasil tes awal penguasaan konsep pada kelas eksperimen diperoleh 43,37 sedangkan pada kelas kontrol sebesar 46,61. Dan diperoleh rata-rata hasil tes akhir sebesar 91,06 pada kelas eksperimen dan 83,00 pada kelas kontrol (Gambar 1). Sehingga diperoleh N-gain yang tergolong tinggi untuk kelas eksperimen $(0,806)$ sedangkan pada kelas kontrol N-gain tergolong sedang $(0,656)$.

Hasil analisis uji Shapiro-Wilk menunjukkan bahwa data tes awal dan tes akhir kedua kelas penelitian tidak berdistribusi normal dikarenakan nilai signifikansi yang diperoleh $<0,05$. Data yang diperoleh juga termasuk kedalam data homogen karena nilai signifikansi $>0,05$. Dan berdasarkan Uji Mann-Whitney, dinyatakan bahwa terdapat pengaruh demonstrasi penggunaan media buku рор up terhadap motivasi dan penguasaan konsep siswa, dikarenakan nilai signifikansi $<0,05$.

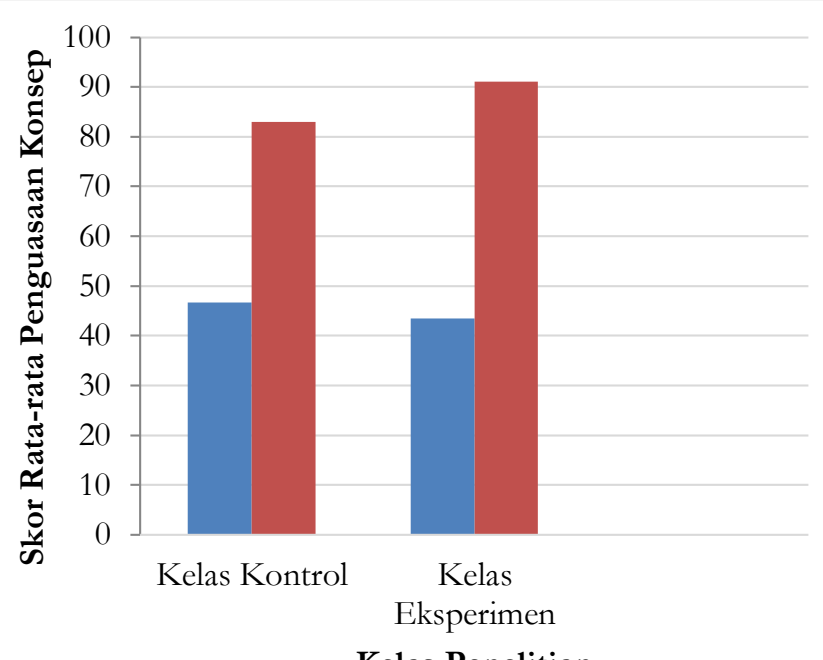

Kelas Penelitian

- Tes Awal $\square$ Tes Akhir

Gambar 1. Perbandingan hasil tes awal dan tes akhir pada kelas eksperimen dan kelas kontrol

Berdasarkan Gambar 1, rata-rata nilai tes awal dan nilai tes akhir pada kelas eksperimen mengalami peningkatan. Nilai pada kelas eksperimen lebih unggul dari kelas kontrol, hal tersebut menunjukkan adanya pengaruh media buku pop up terhadap hasil belajar penguasaan konsep (kognitif). Meskipun kedua kelas penelitian samasama mengalami peningkatan pada skor akhir, nilai skor akhir yang didapatkan pada kelas eksperimen lebih besar. Begitu pun dengan nilai N-gain yang diperoleh kelas eksperimen lebih besar dari nilai $\mathrm{N}$-gain pada kelas kontrol. Berdasarkan hal tersebut dapat dikatakan bahwa materi sistem endokrin pada kelas yang menggunakan media $p o p$ up dapat lebih mudah dipahami walau pun disampaikan secara demonstrasi. Karena pada saat media 
didemonstrasikan perhatian siswa tertuju pada media $p \circ p$ up sehingga siswa menjadi lebih fokus. Hasanah (2019) berpendapat bahwa rata-rata selisih hasil belajar pada kelas eksperimen lebih besar dari kelas kontrol. Data tersebut dapat dikatakan bahwa rata-rata selisih hasil belajar kelas eksperimen lebih tinggi dibandingkan kelas kontrol. Maka media buku $р о p$ up pada materi sistem endokrin lebih mudah dipahami dibandingkan tidak menggunakan media buku $p$ ор up. Hal ini menunjukkan bahwa penggunaan media $p \circ p$ up pada materi sistem endokrin lebih mudah dipahami dibandingkan dengan media konvensional.

Selain itu, penggunaan buku pop up yang disampaikan secara daring dengan metode demonstrasi ini memiliki beberapa kelebihan, selain meningkatkan pemaham pada materi sistem endokrin, penggunaan buku pop up dapat menarik perhatian siswa pada saat pembelajaran. Pada saat buku $р о р$ и didemonstrasikan dalam kelas eksperimen, perhatian siswa tertuju pada media $р о д$ и yang digerakkan dan siswa terlihat sangat antusias dengan melontarkan pertanyaan-pertanyaan terkait buku pop up pada awal pembelajaran. Pembelajaran dilakukan melalui aplikasi meetings online Cisco WEBEX karena adanya pandemi, menjadikan siswa hanya melihat buku рор ир dari layar saja. Metode yang dipilih pun disesuaikan yaitu metode demonstrasi media dan ceramah. Hal-hal tersebut membuat siswa tidak terlibat aktif dalam pembelajaran. Hal tersebut sejalan dengan pendapat Safri et al. (2017) terikait proses pembelajaran dengan metode ceramah yang berpusat pada guru membuat peserta didik cenderung mendengarkan dan tidak terlibat aktif selama pembelajaran.

\section{Motivasi siswa setelah pembelajaran menggunakan media pop up}

Motivasi belajar siswa dilihat dari skor rata-rata tiap komponen motivasi yang terdiri dari empat komponen yaitu attention atau perhatian, relevance atau relevansi, confidence atau kepercayaan diri, satisfaction atau kepuasan. Kemudian dari skor rata-rata tiap komponen motivasi tersebut, dapat dilihat termasuk kategori motivasi belajar apa yang ditunjukan siswa. Rekaptulasi hasil motivasi belajar siswa dapat dilihat pada tabel berikut.

Tabel 1. Rekaptulasi rata-rata skor motivasi belajar per komponen pada kelas eksperimen dan kelas kontrol

\begin{tabular}{llllll}
\hline \multirow{2}{*}{$\begin{array}{c}\text { Komponen } \\
\text { Motivasi }\end{array}$} & \multicolumn{2}{c}{$\begin{array}{c}\text { Kelas } \\
\text { Eksperimen }\end{array}$} & \multicolumn{2}{c}{ Kelas Kontrol } & \multirow{2}{*}{ Gain } \\
\cline { 2 - 5 } & Skor & Kategori & Skor & Kategori & \\
\hline Attention & 3,10 & Tinggi & 2,76 & Tinggi & 0,34 \\
Relevance & 3,17 & Tinggi & 2,83 & Tinggi & 0,34 \\
Confidence & 3,08 & Tinggi & 2,73 & Tinggi & 0,35 \\
Satisfaction & 3,21 & Tinggi & 2,83 & Tinggi & 0,38 \\
Rata-rata & 3,14 & Tinggi & 2,78 & Tinggi & 0,35 \\
skor total & & & & & \\
\hline
\end{tabular}

Berdasarkan data tersebut, kedua kelas termasuk dalam kategori motivasi belajar yang sama, baik kelas eksperimen dan kelas kontrol termasuk ke dalam kategori tinggi. Skor rata-rata yang didapat kelas eksperimen sebesar 3,14 sedangkan pada kelas kontrol diperoleh rata-rata sebesar 2,78 dengan nilai N-gain sebesar 0,35 yang termasuk dalam kategori sedang (Gambar 2). Oleh karena skor motivasi belajar pada kelas eksperimen lebih tinggi daripada kelas kotrol, dapat dikatakan bahwa penggunaan media pop up pada materi sistem endokrin berhasil meningkatkan motivasi belajar siswa.

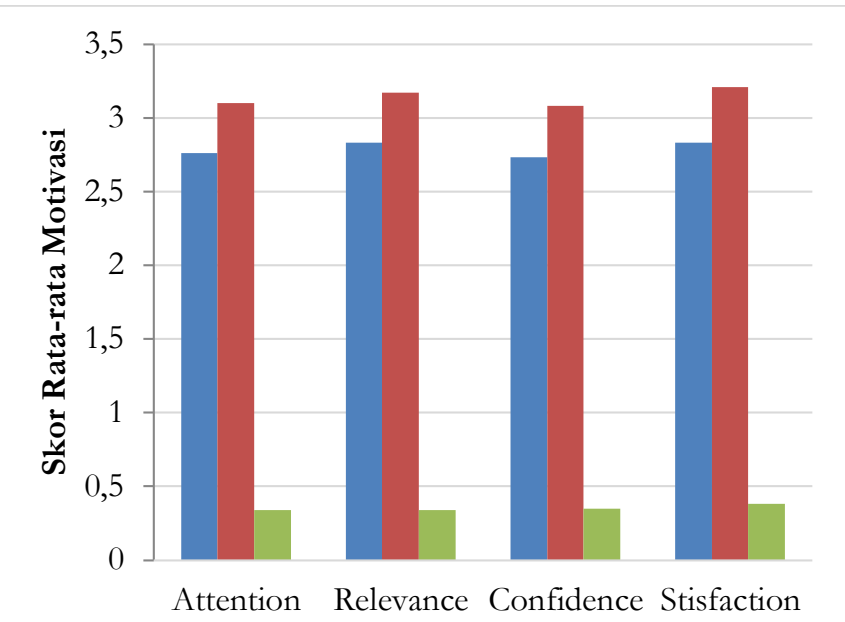

Komponen Motivasi Belajar

- Kontrol aksperimen $\square$ Gain

Gambar 2. Perbandingan rata-rata skor motivasi belajar per komponen pada kelas eksperimen dan kelas kontrol

Hasil penelitian tersebut menunjukkan bahwa komponen perhatian terbilang tinggi, hal tersebut menunjukkan bahwa siswa memberikan perhatian atau atensi yang tinggi terhadap proses pebelajaran menggunakan media demonstrasi. Memperhatikan merupakan sikap yang mudah dilaksanakan oleh siswa. Hal tersebut sesuai dengan penelitian Indah et al., (2018) yang menjelaskan bahwa aspek perhatian memiliki persentase yang cukup tinggi, karena siswa pada tingkat Sekolah Menengah Atas telah memiliki kesadaran yang tinggi untuk memfokuskan pikiran ketika pelajaran di kelas. Komponen relevansi yang tinggi menunjukkan bahwa penyampaian tujuan pembelajaran dapat diterima dengan baik oleh siswa, tujuan pembelajaran tercapai, dan siswa merasa akan memperoleh manfaat dari mempelajari materi sistem endokrin dengan bantuan media $р о p$ up. Komponen kepercayaan diri dalam penelitian ini menunjukkan bahwa siswa mengalami peningkatan motivasi belajar dalam aspek percaya diri, dimana siswa menunjukkan keberanian dalam menyampaikan pendapat maupun dalam bertanya dan menjawab pertanyaan yang diberikan, siswa juga mampu menyelesaikan tes dan tugas-tugas secara mandiri. Komponen kepuasan menjadi komponen dengan perolehan nilai $\mathrm{N}$-gain tertinggi dari keempat komponen lainnya. Menurut Indah et al. (2018) aspek kepuasan berhubungan dengan rasa percaya diri, hal tersebut berarti semua siswa menyelesaikan seluruh tugas yang diberikan selama pembelajaran, hal ini berkaitan karena komponen kepercayaan diri merupakan komponen tertinggi kedua setelah kepuasan.

Maka berdasarkan penjelasan tersebut, media buku pop up dapat meningkatkan motivasi siswa dalam belajar. Ada pun kategori motivasi belajar kedua kelas penelitian 
yang terbilang tinggi, dapat dikarenakan pembelajaran secara daring merupakan sesuatu yang baru bagi siswa baik pada kelas eksperimen maupun pada kelas kontrol yang mana hal tersebut merupakan salah satu variabel pengganggu dan kelemahan dari penelitian ini. Variabel pengganggu menyebabkan hasil dari penelitian pada kelas eksperimen dan kelas kontrol tidak jauh berbeda bahkan termasuk ke dalam kategori yang sama-sama tinggi . hal tersebut dikarenakan pembelajaran jarak jauh yang diselenggarakan ditengah pandemi sehingga mengharuskan siswa belajar dari rumah menjadikan siswa hanya melihat buku menjadi berkurang. Maka dari itu, keefektifan media menjadi berkurang karena digunakan metode demonstrasi media.

Adapun data yang didapatkan bahwa terdapat pengaruh antara motivasi dan pengusaan konsep dalam pembelajaran menggunakan media buku pop up yang didemonstrasikan. Didapatkan data bahwa nilai signifikansi $<$ 0,05 maka terdapat pengaruh antara kedua variabel dengan perolehan koefisien 0,630 yang termasuk kuat. Siswa yang mempunyai motivasi belajar yang tinggi, akan terdorong dengan berbagai cara untuk meningkatkan prestasi belajarnya. Beberapa penelitian tentang hasil belajar yang diperoleh siswa menunjukkan motivasi sebagai faktor yang berpengaruh terhadap proses belajar dan hasil belajar (Riyanto et al., 2013).

\section{Tanggapan atau respon siswa terhadap media pop up sebagai media pembelajaran}

Hasil angket respon siswa menunjukkan bahwa sebagian besar siswa memberikan respon yang baik terhadap pelaksaan demonstrasi media buku рор ир. Siswa menyatakan meyenangi dan bersemangat mengikuti pembelajaran menggunakan media $p o p$ up dengan materi sistem endokrin. Buku pop up dapat dilihat pada Gambar 3.

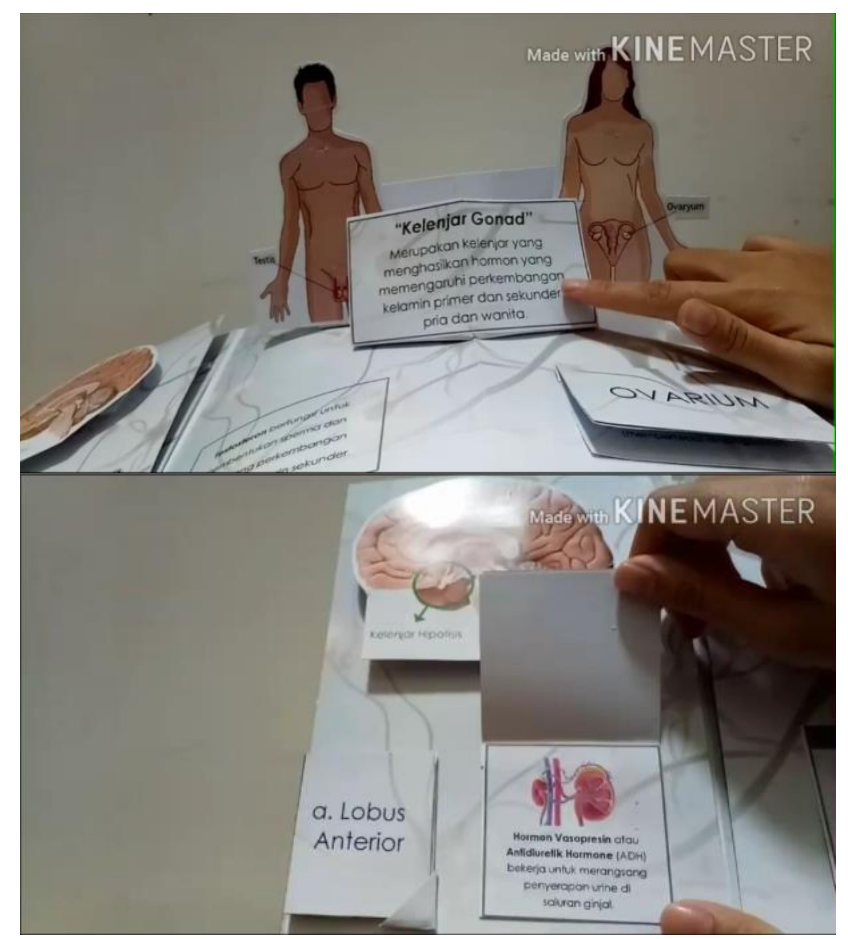

Gambar 3. Penggalan halaman dari buku $p \circ p$ up materi sistem endokrin yang digunakan dalam penelitian

\section{SIMPULAN}

Terdapat pengaruh penggunaan media pembelajaran buku pop up yang dilakukan secara demonstrasi terhadap motivasi dan penguasaan konsep siswa. Hal ini dapat dilihat dari perbedaan penguasaan konsep dan motivasi siswa antara kelas eksperimen dan kelas kontrol.Pada kelas eksperimen, penguasaan konsep siswa mengalami peningkatan rata-rata $\mathrm{N}$-gain yang berada dalam kategori tinggi setelah menerapkan $p \circ p$ up sebagai media belajar. Sedangkan rata-rata $\mathrm{N}$-gain yang didapat untuk kelas kontrol berada dalam kategori sedang. Dalam penelitian ini juga didapatkan bahwa rata-rata skor motivasi belajar secara keseluruhan antara kelas eksperimen dan kelas kontrol berbeda. Kelas eksperimen mendapat skor rata-rata yang lebih tinggi dari kelas kontrol, dan diperoleh nilai $\mathrm{N}$ gain dalam kategori sedang. Respon siswa pada pembelajaran ini termasuk ke dalam kategori tinggi yang mampu menumbuhkan rasa ketertarikan terhadap pembelajaran yang ditandai dengan rasa senang.

\section{REFERENSI}

Anggraini, W., Nurwahidah, S., Asyhari, A., Reftyawati, D., \& Haka, N. B. (2019). Development of Pop-Up Book Integrated with Quranic Verses Learning Media on Temperature and Changes in Matter. Journal of Physics: Conference Series, 1155(1). https:/ / doi.org/10.1088/1742-6596/1155/1/012084

Anwariningsih, S. H., \& Ernawati, S. (2013). Development of Interactive Media for ICT Learning at Elementary School Based on Student Self Learning. Journal of Education and Learning (EduLearn), 7(2), 121. https://doi.org/10.11591/edulearn.v7i2.226

Djamarah, Syaiful, B., \& Zain, A. (2010). Strategi Belajar Mengajar. Jakarta: Rineka Cipta.

Hasanah, U. (2019). Pengaruh Media Pop Up Book Terhadap Hasil Belajar Siswa Pada Mata Pelajaran Ipa Kelas V Sd Negeri 99 Kota Bengkulu. Institut Agama Islam Negeri, Bengkulu.

Indah, D. S., Sunarno, W., \& Sarwanto, S. (2018). Pengembangan Modul Fisika Berbasis Savi (Somatic, Auditory, Visualization, Intellectually) Untuk Meningkatkan Motivasi Siswa Pada Pembelajaran Fisika Kelas X SMK Jurusan Multimedia Dengan Topik Impuls Dan Momentum. INKUIRI: Jurnal Pendidikan IPA, 7(2), 273. https://doi.org/10.20961/inkuiri.v7i2.22988

Keller, J. (2000). How to integrate learner motivation planning into lesson planning: The ARCS model approach. Florida: Florida State University.

Okamura, S., \& Igarashi, T. (2011). An Assistant Interface to Design and Produce a Pop-Up Card. International Journal of Creative Interfaces and Computer Graphics, 1(2), 40-50. https://doi.org/10.4018/jcicg.2010070104

Riyanto, Sudjarwo, \& Herpratiwi. (2013). Studi Korelasi Antara Motivasi Belajar, Media Pembelajaran, Kemampuan Awal, Dengan Hasil Belajar. https://doi.org/10.1017/CBO9781107415324.004

Safri, M., Sari, S. A., \& Marlina. (2017). Pengembangan Media Belajar Pop-Up Book Pada Materi Minyak 
Bumi. Jurnal Pendidikan Sains Indonesia (Indonesian Journal of Science Education), 5(1), 107-113.

Sari, S. A. (2017). The Development of Pop-up Book on the Role of Buffer in the Living Body. European Journal of Social Sciences Education and Research, 10(2), 213. https://doi.org/10.26417/ejser.v10i2.p213-221

\section{Conflict of Interest Statement}

The author(s) declare that the research was conducted in the absence of any commercial or financial relationships that could be construed as a potential conflict of interest.

\section{How to Cite}

Nurhanifah, N., Hamdiyati, Y., \& Sanjaya, Y. (2020). Pengaruh demonstrasi penggunaan buku pop up sebagai media pembelajaran terhadap motivasi dan penguasaan konsep siswa pada materi sistem endokrin. Assimilation: Indonesian Journal of Biology Education, 3(2), 69-73. 